ENTREPRENEURSHIP AND SUSTAINABILITY ISSUES

ISSN 2345-0282 (online) http://jssidoi.org/jesi/

2020 Volume 7 Number 4 (June)

http://doi.org/10.9770/jesi.2020.7.4(3)
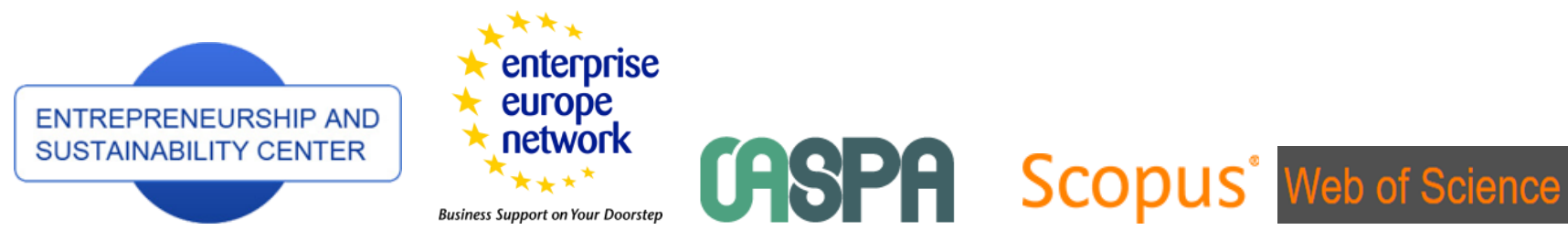

http://jssidoi.org/e

Publisher
oi.org/esc/home

D Clarivate

Analytics

\title{
BAIL-IN AND INTERBANK CONTAGION RISK: AN APPLICATION OF FSQCA METHODOLOGY*
}

\author{
Marc Sanchez-Roger ${ }^{1}$, María Dolores Oliver-Alfonso ${ }^{2}$, Carlos Sanchís-Pedregosa ${ }^{3}$, Norat Roig-Tierno ${ }^{4}$ \\ 1,2,3 Universidad de Sevilla, Avd. Ramón y Cajal, 1. 41018 - Sevilla, Spain \\ ${ }^{3}$ Universidad del Pacífico, Departamento Académico de Administración. Jr. Gral, Jirón Luis Sánchez Cerro 2141, 15072, \\ Lima, Peru \\ ${ }^{4}$ ESIC Business \& Marketing School. Av. de Blasco Ibáñez, 55, 46021 València, Spain \\ E-mails: ${ }^{1} \underline{\text { marsanrog1@alum.us.es }} ;{ }^{2} \underline{\text { moliver@us.es }} ;{ }^{3}$ c.sanchisp@up.edu.pe $;{ }^{4}$ norat.roig@esic.edu
}

Received 26 November 2019; accepted 10 March 2020; published 30 June 2020

\begin{abstract}
This work uses fuzzy set theory and qualitative comparative analysis (QCA) to determine the causal configurations leading to interbank contagion in a resolution event. This study pioneers the introduction of fsQCA methodology in banking crisis analyses. The event providing the necessary data for this study is the resolution of the Spanish bank Banco Popular. We develop sufficient and necessary condition analyses to find the key metrics that lead to interbank contagion. The results demonstrate that weak solvency metrics, low asset quality and belonging to the same country where the resolution has been triggered tend to lead to higher contagion.
\end{abstract}

Keywords: bail-in; banking resolution; FSQCA; contagion risk

Reference to this paper should be made as follows: Sanchez-Roger, M., Oliver-Alfonso, M.D., Sanchís-Pedregosa, C., Roig-Tierno, N. 2020. Bail-in and interbank contagion risk: an application of FSQCA methodology. Entrepreneurship and Sustainability Issues, 7(4), 2604-2614. https://doi.org/10.9770/jesi.2020.7.4(3)

JEL Classifications: G10, G20, G21

\section{Introduction}

Most of the benefits of the post-global financial crisis banking regulations are well known and include improving the resilience of the banking sector, strengthening risk management and corporate governance practices, increasing transparency and minimizing the use of public funds to recapitalize the banking sector in the event of a banking crisis. However, most of the side effects of the new resolution framework remain unknown, with limited academic research focused on these topics.

\footnotetext{
* Norat Roig-Tierno wish to thank Project GV/2019/063, funded by the Generalitat Valenciana, Spain, for supporting this research
} 


\section{ENTREPRENEURSHIP AND SUSTAINABILITY ISSUES}

ISSN 2345-0282 (online) http://jssidoi.org/jesi/

2020 Volume 7 Number 4 (June)

http://doi.org/10.9770/jesi.2020.7.4(3)

A particularly important side effect of the new banking resolution framework comes as a consequence of the contagion effect that could take place between banks when a resolution is triggered. This paper starts with the proposition that the resolution of a banking entity entails a contagion effect that impacts other banks' subordinated debt and equity instruments.

This effect can be seen in the resolution of Banco Popular, where the subordinated and equity instruments of several European banks reacted to the write-down and conversion of Banco Popular equity and subordinated debt instruments. The resolution of Banco Popular is the first case within the European Union where the regulator used the write-down and conversion powers to resolve a banking entity. On June $6^{\text {th }}$, 2017, after shareholders and subordinated bondholders lost their entire investment, Banco Popular was sold to Banco Santander for EUR1 following the sale of a business tool described in the Bank Recovery and Resolution Directive, BRRD (European Commission, 2014).

The resolution of Banco Popular is used as a case study aiming to understand the reaction of the equity and subordinated debt instruments of a sample of EU banks directly supervised by the European Central Bank (ECB). Financial metrics such as solvency, asset quality, profitability or size are taken into account, allowing us to draw conclusions about which banks are more prone to suffer from bail-in contagion while others remain less volatile. In particular, the subordinated debt instruments of Spanish banks with weak solvency and asset quality metrics clearly suffered a strong contagion effect, while others remained almost unaffected after the resolution announcement.

A methodology approach based on fuzzy sets qualitative comparative analysis (fsQCA) is used to determine the causal configurations that lead a bank to suffer higher contagion when the resolution of a bank takes place. Despite rapid development in the use of fsQCA in the field of finance, its use in the area of banking crises is nonexistent according to the authors' best knowledge. This work shows the suitability of fsQCA to study the spillover effects of banking resolutions, therefore opening the door to a new wave of publications on similar subjects. The results of this analysis are relevant from an academic viewpoint and are also particularly important for practitioners including regulators, banks and investors, among other market participants. The findings could be considered helpful in predicting the contagion effects in a potential new case of resolution and, hence, optimizing the portfolio's returns.

This work is structured as follows: the introduction is followed by a theoretical background, section 3 focuses on the methodology, and then section 4 presents the results, followed by the conclusions section.

\section{Theoretical framework}

The resolution of a banking entity is understood as the procedure where one or more resolution tools are applied to achieve the objectives of safeguarding public interest by ensuring the continuity of the bank's critical functions and financial stability at a minimal cost for taxpayers (Single Resolution Board, 2016). In Europe, this process is triggered when the ECB determines that a bank is "failing or likely to fail", after the recovery plan proposed by the single supervisory mechanism (SSM) has failed. The Single Resolution Board (SRB), the central resolution authority within the Banking Union, has the responsibility of deciding whether a resolution is in the public interest and no other supervisory or private measures can restore confidence in the bank, or if the entity has to be liquidated. In the case of liquidation, the national insolvency laws will apply and the SRB will not be in charge of leading the process. This was the case for Banca Popolare Vicenza, Veneto Banca and ABLV Bank in 2017 and early 2018, respectively (Single Resolution Board, 2017a, 2017b, 2018). 


\section{ENTREPRENEURSHIP AND SUSTAINABILITY ISSUES}

ISSN 2345-0282 (online) http://jssidoi.org/jesi/

2020 Volume 7 Number 4 (June)

http://doi.org/10.9770/jesi.2020.7.4(3)

If conditions for resolution are met and the European Commission approves the resolution scheme, the SRB will go ahead with the resolution process and apply a resolution tool, or a combination of them. As stated by the single resolution mechanism (Single Resolution Board, 2016), before any resolution tool is applied, the capital instruments of the entity must be converted into equity or written down. This implies that in any resolution case, equity and subordinated debt instruments should be impacted; hence, this work focuses on interbank contagion risk by analyzing the market performance of these instruments.

There is a small but growing body of literature on the subject of the unintended consequences of the new banking resolution procedures and particularly on the spillover effects of the bail-in tool (Avgouleas \& Goodhart, 2015; De Grauwe, 2013; Hüser et al., 2017). Among the many spillover effects linked to the current banking resolution framework, financial contagion is a relevant effect, attracting the interest of researchers and practitioners. Financial contagion has been traditionally widely explored by academia due to its significant importance in both financial crises and the real economy (Allen \& Gale, 2000; Pericoli \& Sbracia, 2003).

As highlighted in previous literature, the bail-in tool or the write-down and equity conversion powers of debt and equity instruments can cause contagion across the banking sector (Havemann, 2018). Therefore, this work focuses on the degree of contagion between banks by analyzing the performance of such instruments in secondary markets in the event of a resolution.

Among the several channels through which financial contagion could take place, information contagion is one of the most relevant within the banking sector (Ahnert \& Georg, 2012). There are diverse reasons for banks' investors to consider information about other banks as a key input for their investment decisions. First, two given banks could have equity and debt cross-holdings as well as interbank loans. Second, both banks could share exposure to the same kind of assets. This should imply that the information about the solvency or asset quality of a given bank could provide relevant insights about the financial soundness of other banks (Acharya \& Yorulmazer, 2008).

In this work, we leverage the information contagion theory to analyze direct contagion across banks streaming from a bank resolution event. Following Iyer and Peydró, we use their broad definition of contagion between banks: "contagion takes place when the failure of a bank triggers a significant negative externality to other banks" (Iyer \& Peydró, 2010). In particular, we measure this externality in the equity and subordinated debt market in our work. We acknowledge that measuring contagion risk and obtaining conclusions is not new. However, when focusing strictly on contagion arising from a bank resolution, the academic literature is almost nonexistent, which contrasts with its relevant implications for regulators, bank supervisors and market participants. Therefore, this work focuses on answering which causal configurations lead to interbank contagion in a resolution scenario.

\section{Methodology}

\subsection{Case study and method}

The case under study is the resolution of Banco Popular. We will draw relevant conclusions regarding interbank contagion from data compiled during the Banco Popular resolution event. On June $6^{\text {th }}, 2017$, the ECB notified the SRB that Banco Popular was "failing or likely to fail" on the grounds of a severe deterioration of the liquidity situation, given the solvency concerns linked to the extraordinary provisions disclosed in February 2017 and several downgrades from rating agencies, among other factors (European Parliament, 2017). Following the notification, the SRB, in coordination with the Spanish Resolution Fund (FROB) deemed that resolution was in the public interest and that no other feasible private options were available and therefore triggered the resolution procedure. The resolution tool applied was the sale of the business to Banco Santander with a previous write- 


\section{ENTREPRENEURSHIP AND SUSTAINABILITY ISSUES}

ISSN 2345-0282 (online) http://jssidoi.org/jesi/

2020 Volume 7 Number 4 (June)

http://doi.org/10.9770/jesi.2020.7.4(3)

down and conversion of capital instruments. In practical terms, this is very similar to the use of the bail-in tool for junior subordinated and subordinated instruments.

To achieve the goal of understanding the key variables that lead to interbank contagion following the announcement of a bank resolution, this work uses the fuzzy set qualitative comparative analysis (fsQCA) methodology. This work contributes to the development of fsQCA as a technique to deal with banking crises. We find some references using fsQCA methodology to deal with bankruptcy from a general viewpoint (Boratyńska, 2016; Boratyńska \& Grzegorzewska, 2018) or even to understand fiscal policy reactions or regulatory responses to the global financial crisis (Hörisch, 2013; Young \& Park, 2013). However, the current literature using fsQCA in the field of banking financial analysis is scarce, with Pinto and Picoto (2018) being one of the few articles where the methodology is used. In particular, the authors use fsQCA to explore whether the levels of loan loss provisions can be explained by the banks' size and the level of nonperforming loans.

fsQCA is an analytical technique that combines the use of fuzzy set theory, Boolean algebra and comparison techniques (Ragin, 1987, 2000, 2008). Fuzzy sets are considered to be an extension of the classic set theory and can be defined as sets whose elements have different degrees of membership (Zadeh, 1965). Many authors concur that the calibration of fuzzy sets is a key step when dealing with methodologies where fuzzy set theory is involved (Woodside \& Zhang, 2013). In line with the literature, the calibration of fuzzy sets implies a transformation process of the original variables into fuzzy numbers that represent a degree of membership.

Once the calibration of fuzzy sets has been completed, the use of QCA methodology allows the identification of the presence (absence) of a given attribute necessary or sufficient for the presence (absence) of a particular output. In our study, this output is financial contagion. fsQCA methodology consists of simultaneously performing a necessary condition and a sufficiency condition analysis. In the necessary condition test, a condition is called necessary if the outcome cannot take place without this condition (Ragin, 2014). Regarding the sufficiency test, a condition or causal configuration is called sufficient if it is enough to reach a given outcome. However, this does not rule out other ways to obtain the outcome (Ragin, 2014).

In this methodology, variables are known as conditions allowing the identification of different configurations that lead to a given outcome. In our study, the outcome is interbank contagion through equity and the banks' subordinated debt instruments, and the conditions are key credit fundamental metrics.

One of the key strengths of fsQCA is its ability to identify causal relationships behind a given outcome, which is particularly relevant in highly uncertain environments where several variables are somewhat related to the output. Our work exploits the fsQCA capacity to detect such conditions and allows us to draw relevant conclusions regarding interbank contagion through equity and debt financial markets in the event of a bank resolution. In addition, fsQCA does not require a large dataset to apply the method, which is particularly relevant in our case where we study a single resolution event and the dataset contains information about a limited number of European banks under the supervision of the ECB (Fiss, 2011).

\subsection{Data}

We make use of two databases that we have developed for the purpose of this work. The first one contains fundamental data from the sample of EU banks included in this analysis. The sample is composed of 37 European banks directly supervised by the ECB that satisfy the condition of having at least one of the following instruments traded actively in a secondary market at the time of Banco Popular's resolution: equity, Additional Tier 1 and Tier 2. Data for this database are obtained as of 1Q17 from the banks' quarterly reports; when no quarterly data are available, the information is obtained from the 2016 annual accounts. In particular, we focus on 5 key fundamental metrics including solvency, asset quality, profitability, size, and country. We have chosen these 


\section{ENTREPRENEURSHIP AND SUSTAINABILITY ISSUES}

ISSN 2345-0282 (online) http://jssidoi.org/jesi/

2020 Volume 7 Number 4 (June)

http://doi.org/10.9770/jesi.2020.7.4(3)

conditions since they are commonly used to rate the banks' credit quality. Table 1 summarizes the information stored in both databases.

Table 1. Description and data sources

\begin{tabular}{llll}
\hline Outcome/Conditions & Description/Measure & Source & Database \\
\hline Solvency & Common Equity Tier 1 ratio & Company reports & Database 1 \\
Asset quality & Nonperforming loans ratio & Company reports & Database 1 \\
Profitability & Return on Equity & Company reports & Database 1 \\
Size & Total Assets & Company reports & Database 1 \\
Country & Country where the parent company is based & Company reports & Database 1 \\
Contagion effect (Outcome) & Market performance of: i) Equity, ii) AT1, and iii) Tier 2 & Market data - Bloomberg & Database 2 \\
\hline
\end{tabular}

Source: Authors

The second database that we use in this study contains data on the different securities issued by the banks in our sample, including equity, Additional Tier 1 and Tier 2, and their weekly trading levels since early 2016 until the date of the resolution of Banco Popular. Data are obtained from Bloomberg, and we exclude Additional Tier 1 and Tier 2 instruments that are not actively traded in a secondary market. We use the performance of equity, AT1 and Tier 2 instruments during the month prior to the resolution of Banco Popular until the day that the resolution was announced. This allows us to capture not just the impact of the resolution announcement but also the rumors and leaks about a potential resolution that led market participants to start anticipating a resolution of the bank some days prior to the official announcement. Next, we describe the calibration approach followed for each condition.

\subsection{Conditions and calibration}

As part of the fsQCA methodology, each condition and outcome is calibrated to identify if it belongs to a given set. In short, we have identified the degree of membership of each condition to the set. For example, the calibration of "Contagion effect" consists of identifying if a bank belongs to the set "contagion" (fuzzy value of 1) or does not belong at all (value of 0). Furthermore, the degree of membership could take any value from 1 to 0 . In this work, the calibration method applied is the direct method proposed by (Ragin, 2014). The use of this calibration method implies that 3 thresholds have to be defined: full membership, full non-membership and the maximum ambiguity point.

The conditions related to the contagion effect under analysis are as previously described: asset quality, solvency, profitability, size and country. Next, we elaborate on the condition and define the calibration approach followed in each case.

To measure the banks' asset quality, we use the variable "Non Performing Loans" ratio (NPL), since this is the most commonly used metric to analyze the asset quality of a bank (European Parliament, 2018). To define the threshold, we use the European Banking Authority (EBA) threshold levels, which allow us to classify the banks in 3 groups depending on their asset quality levels (European Banking Authority, 2018). In particular, we classify banks with NPL ratios below $3 \%$ as strong asset quality banks and above $8 \%$ as having a weak asset quality. The crossover point was considered the average between the 2 thresholds.

With regard to solvency, in line with the ECB, the EBA and most of the international organizations, we use the CET1 ratio, which is calculated as Common Equity Tier 1 capital divided by risk weighted assets. Following the EBA classification, we consider banks having a CET1 ratio above $14 \%$ as having a strong asset quality, and weak 
asset quality as those banks with a ratio below $11.5 \%$. Once again, the maximum ambiguity point is defined as the average between the 2 thresholds.

Regarding profitability, we use the return on equity (RoE), which is also a very common indicator for profitability and is used by several regulatory and supervisory bodies. Again, we have followed the thresholds used by the EBA. We establish the following thresholds: high profitability $(\operatorname{RoE}>10 \%)$, low profitability $(\operatorname{RoE}<0 \%)$ and the maximum ambiguity point, which was considered the average between the 2 thresholds.

Regarding the size of the banking entity, we follow the ECB approach, classifying the banks' size based on their total assets. In this case, we have slightly changed the thresholds used by the ECB to adapt to our sample of banks and obtain more insightful results. The classification is as follows: very large international institutions (total assets>EUR500bn), small size banks (total assets<EUR50bn), and the crossover point was considered to be the average between the 2 thresholds. Finally, we also take into account the condition "country", which refers to the country where the parent company of each banking group is based. Table 2 summarizes the main descriptive statistics and the anchors of calibration for the conditions.

Table 2. Descriptive statistics and conditions calibration

\begin{tabular}{lllllll}
\hline Conditions/Outcome & Fully In & $\begin{array}{l}\text { Crossover } \\
\text { Point }\end{array}$ & Fully out & Max & Min & $M(S D)$ \\
\hline Asset quality & 2 & 5.5 & 8 & 58.23 & 0.50 & $\begin{array}{l}12.02 \\
(13.11)\end{array}$ \\
Solvency & 14 & 12.75 & 11.5 & 19.50 & 8.15 & $\begin{array}{l}13.72 \\
(2.25)\end{array}$ \\
Profitability & 10 & 5 & 0 & 15.81 & -36.07 & $\begin{array}{l}2.26 \\
(9.88)\end{array}$ \\
Size & 500 & 275 & 50 & 2076.96 & 7.04 & $\begin{array}{l}381.99 \\
(505.17)\end{array}$ \\
Country & $\begin{array}{l}\text { Dichotomous conditions. Presence (1) or Absence (0) of the bank in the } \\
\text { country where the resolution takes place (Spain). }\end{array}$ \\
\hline
\end{tabular}

Source: Authors

Regarding the outcome, we use the equity, Additional Tier 1 (AT1) and Tier 2 market performance to classify banks. Focusing on the performance of the three asset classes, we have classified banks into four categories: i) no contagion, ii) low contagion, iii) moderate contagion and iv) high contagion. The next table shows the thresholds we have used in the different asset classes to classify banks in the four groups just mentioned. In the case of equity instruments, we have used the monthly share price performance from one month prior to the resolution announcement until June $6^{\text {th }}$, 2017, when the resolution took place as inputs. Regarding the AT1 and Tier 2 instruments, we use the asset swap spread (ASW) performance in basis points (bp) during the same timeframe.

Table 3. Calibration of the outcome

\begin{tabular}{lllll}
\hline & No Contagion & Low Contagion & Moderate Contagion & High Contagion \\
\hline Equity & $\Delta$ Equity $\geq 0 \%$ & $0 \%>\Delta$ Equity $\geq 3 \%$ & $-3 \%>\Delta$ Equity $\geq-10 \%$ & $\Delta$ Equity $<-10 \%$ \\
AT1 & $\Delta \mathrm{AT} 1 \leq 0 \mathrm{bp}$ & $0 \mathrm{bp}<\Delta \mathrm{AT} 1 \leq 10 \mathrm{bp}$ & $10 \mathrm{bp}<\Delta \mathrm{AT} 1 \leq 25 \mathrm{bp}$ & $\Delta \mathrm{AT} 1>25 \mathrm{bp}$ \\
Tier 2 & $\Delta \mathrm{Tier} 2 \leq 0 \mathrm{bp}$ & $0 \mathrm{bp}<\Delta$ Tier $2 \leq 10 \mathrm{bp}$ & $10 \mathrm{bp}<\Delta$ Tier2 $\leq 20 \mathrm{bp}$ & $\Delta$ Tier $2>20 \mathrm{bp}$ \\
$\begin{array}{l}\text { Degree of membership for the } \\
\text { outcome (Contagion) }\end{array}$ & 0 & 0.25 & 0.75 & 1 \\
\hline
\end{tabular}

Source: Authors 


\section{Results and interpretation}

\subsection{Conditions and calibration}

Table 4 shows the results of the necessary condition analysis. At first glance, it is evident in the first two columns (fs_cont) that there is no necessary condition that leads to contagion because the consistency values are lower than 0.9 (García Álvarez-Coque, Mas-Verdú, \& Roig-Tierno, 2017). However, when focusing on the absence of contagion, we find that not being in the country where the resolution took place is a necessary condition to avoid contagion (consistency 0.9). In addition, we have identified solvency as an almost necessary condition to avoid contagion (Schneider, Schulze-Bentrop, \& Paunescu, 2010). The results are in line with our initial proposition highlighting that solvency and the country where the bank's parent company is based are particularly relevant. We acknowledge that in complex scenarios where several conditions can play a key role, finding a necessary condition to determine a given output is rare. Therefore, the sufficient condition analysis that we develop next highlights the combination of conditions that lead to contagion.

Table 4. Necessary condition analysis

\begin{tabular}{llllll}
\hline \multirow{2}{*}{ Conditions tested } & \multicolumn{2}{l}{ Contagion } & & \multicolumn{2}{l}{ Absence of Contagion } \\
\cline { 2 - 3 } \cline { 5 - 5 } Solvency & Consistency & Coverage & & Consistency & Coverage \\
$\sim$ Solvency & 0.546157 & 0.533206 & & $\mathbf{0 . 8 7 9 3 8 7}$ & 0.553634 \\
Asset quality & 0.542793 & 0.874666 & & 0.258550 & 0.268669 \\
$\sim$ Asset quality & 0.430186 & 0.669929 & & 0.506002 & 0.508147 \\
Profitability & 0.684163 & 0.682305 & & 0.671322 & 0.431733 \\
$\sim$ Profitability & 0.569733 & 0.714858 & & 0.525064 & 0.424840 \\
Size & 0.541605 & 0.638781 & 0.647591 & 0.492534 \\
$\sim$ Size & 0.439986 & 0.681020 & 0.426008 & 0.425210 \\
Country & 0.628645 & 0.629407 & 0.680421 & 0.439308 \\
$\sim$ Country & 0.280374 & 0.833333 & 0.086957 & 0.166667 \\
\multicolumn{2}{c}{ Note. The suffix "fs" means that the condition is calibrated, and “ " means the absence of the condition. }
\end{tabular}

Source: Authors

\subsection{Analysis of sufficient condition}

The next table shows the results of the sufficiency analysis. We have developed two different models to deal with the sufficiency condition analysis. Model 1 focuses on the solvency, asset quality, profitability and size conditions, while Model 2 adds the country condition. The fact that Model 1 has three possible configurations while Model 2 has six is explained by equifinality, one of the key properties of fsQCA. In this context, we understand equifinality as the existence of multiple paths or solutions to a particular outcome (Elliot, 2013). For each of the models, we find a group of combinations that lead to contagion. According to (Ragin, 2014), the results obtained in both models are consistent (solution consistency $>0.75$ ). We present the results in the next table, following Fiss (2011). 
Table 5. Sufficiency analysis

\begin{tabular}{|c|c|c|c|c|c|c|c|c|c|}
\hline & \multicolumn{3}{|c|}{$\begin{array}{l}\text { Contagion } \\
\text { (Model 1) }\end{array}$} & \multicolumn{6}{|c|}{$\begin{array}{l}\text { Contagion } \\
\text { (Model 2) }\end{array}$} \\
\hline & 1 & 2 & 3 & 1 & 2 & 3 & 4 & 5 & 6 \\
\hline Solvency & $\bigcirc$ & $\bigcirc$ & & $\bigcirc$ & $\bigcirc$ & $\bigcirc$ & & $\bullet$ & $\bigcirc$ \\
\hline Asset Quality & ○ & & $\bigcirc$ & $\bullet$ & & ० & ○ & ० & o \\
\hline Profitability & & $\bullet$ & ○ & $\bullet$ & $\bullet$ & $\circ$ & $\bullet$ & ० & $\circ$ \\
\hline Size & & & & & $\bullet$ & $\circ$ & $\circ$ & $\bullet$ & \\
\hline Country & & & & & & & & & o \\
\hline Unique coverage (cov.u) & 0.436 & 0.315 & 0.185 & 0.188 & 0.201 & 0.237 & 0.113 & 0.056 & 0.218 \\
\hline Raw coverage (cov.r) & 0.175 & 0.095 & 0.045 & 0.044 & 0.035 & 0.022 & 0.023 & 0.012 & 0.031 \\
\hline Consistency (incl.) & 0.904 & 0.927 & 0.859 & 0.953 & 0.924 & 0.900 & 1.000 & 1.000 & 0.855 \\
\hline Solution coverage & & 0.577 & & & & 0.5 & & & \\
\hline Solution consistency & & 0.883 & & & & 0. & & & \\
\hline
\end{tabular}

Note. As in Fiss (2011), $\bullet$ means the presence of the condition. $\circ$ means the absence of the condition. Large circles mean the core condition, and small circles mean the peripheral condition.

Source: Authors

Regarding Model 1, we observe three different sufficiency configurations that could lead to interbank contagion in the case of resolution. In particular, the first combination shows that banks with very low solvency levels combined with low asset quality will experience contagion. The second combination again highlights weak solvency as one of the key drivers for contagion, while the third configuration highlights a very weak asset quality combined with a large volume of total assets.

Regarding the second model, when including the country condition, the results are in line with those obtained in Model 1 and highlight the lack of solvency as one of the main drivers that lead to contagion. In addition, a weak asset quality is once again relevant with regard to contagion. Finally, we clearly observe that belonging to the country where the resolution has been triggered is also extremely relevant, as seen in combinations 4 and 5 in Model 2.

Regarding the profitability and size conditions, the analysis shows mixed results, hence suggesting that these two conditions are not key items for predicting contagion in a resolution environment. 


\section{ENTREPRENEURSHIP AND SUSTAINABILITY ISSUES}

ISSN 2345-0282 (online) http://jssidoi.org/jesi/

2020 Volume 7 Number 4 (June)

http://doi.org/10.9770/jesi.2020.7.4(3)

\section{Conclusion}

As per the best of the authors' knowledge, this work represents the first study to use fsQCA methodology in the field of banking crises and banking resolution. This methodology proves to be particularly adequate in analyzing complex causal relationships, therefore opening the door to the use of fsQCA in the study of financial crises and the spillover effects of banking regulatory frameworks, among other areas.

Overall, the results indicate that banks with weak solvency metrics and a low asset quality tend to suffer higher contagion when a resolution is announced. In addition, a bank belonging to the country where the resolution has been triggered also tends to be related to a higher contagion risk. On the other hand, profitability and size seem to be much less relevant with regard to interbank contagion.

In particular, from the necessary condition analysis, we can conclude that there is not a single condition that could lead to contagion on a stand-alone basis. However, when focusing on the necessary conditions to avoid contagion, we do observe that banks with high solvency ratios and/or banks not based in the country where the resolution takes place generally do not suffer from contagion. Regarding a sufficient condition analysis, the conclusions are straightforward, demonstrating that solvency, asset quality and the country where the bank is based are the three key conditions that explain contagion.

The implications of this work may be relevant from an academic's and practitioner's viewpoint. Particularly from a methodological viewpoint, this study opens the door to the use of fsQCA in the field of banking crises and banking resolution. We believe that fsQCA, which combines fuzzy sets theory and quantitative qualitative approaches, could become a widely used methodology to deal with uncertain and complex environments such as financial crisis analysis in the future. Furthermore, this methodology could be used in future resolution cases, which would increase the accuracy and the relevance of the conclusions obtained from the sufficient and necessary condition analyses. Regarding the practical implications of this work, the conclusions reached contribute to the banking supervisors and regulators' better understanding of the contagion mechanism across banks. In addition, the results highlight which banks could be subject to higher contagion as a result of triggering a bank resolution. The findings of this study could also be used by investors and other market participants to finetune investment strategies in scenarios in which the risk of banking resolution is high.

\section{References}

Acharya, V. V, \& Yorulmazer, T. (2008). Information Contagion and Bank Herding. Journal of Money, Credit and Banking, 40(1), 215231. https://www.jstor.org/stable/25096246

Ahnert, T., \& Georg, C. (2012). Information contagion and systemic risk. Journal of Financial Stability, 35, 159-171. https://doi.org/10.1016/j.jfs.2017.05.009

Allen, F., \& Gale, D. (2000). Financial Contagion. The Journal of Political Economy, 108(1), 1-33.

Avgouleas, E., \& Goodhart, C. (2015). Critical Reflections on Bank Bail-ins. Journal of Financial Regulation, 1(1), 3-29. https://doi.org/10.1093/jfr/fju009

Boratyńska, K. (2016). FsQCA in corporate bankruptcy research. An innovative approach in food industry. Journal of Business Research, 


\section{ENTREPRENEURSHIP AND SUSTAINABILITY ISSUES}

ISSN 2345-0282 (online) http://jssidoi.org/jesi/

2020 Volume 7 Number 4 (June)

http://doi.org/10.9770/jesi.2020.7.4(3)

69(11), 5529-5533. 10.1016/j.jbusres.2016.04.166

Boratyńska, K., \& Grzegorzewska, E. (2018). Bankruptcy prediction in the agribusiness sector: Lessons from quantitative and qualitative approaches. Journal of Business Research, (89(C)), 175-181. https://doi.org/10.1016/j.jbusres.2018.01.028

Elliot, T. Fuzzy-set-qualitative comparative analysis, Research Notes: Statistics Group 1-6 (2013). Retrieved from http://scholar.google.com/scholar?hl=en\&btnG=Search\&q=intitle:Fuzzy+set+qualitative+comparative+analysis\#0

European Banking Authority (EBA). (2018). RISK DASHBOARD - 2Q2018.

European Commission. (2014). Bank Recovery and Resolution Directive (BRRD). Bank Recovery and Resolution Directive (Vol. 2014). European Parliament. (2017). The resolution of Banco Popular.

Fiss, P. C. (2011). Building Better Causal Theories: A Fuzzy Set Approach to Typologies In Organization Research. Academy of Management Journal, 54(2), 393-420. The Academy of Management Journal 54(2) https://doi.org/110.5465/AMJ.2011.60263120

García Álvarez-Coque, J. M., Mas-Verdú, F., \& Roig-Tierno, N. (2017). Technological innovation versus non-technological innovation: different conditions in different regional contexts? Quality and Quantity, 51(5), 1955-1967. https://doi.org/10.1007/s11135-016$\underline{0394-2}$

Grauwe, P. De. (2013). The new bail-in doctrine: A recipe for banking crises and depression in the eurozone. https://www.ceps.eu/cepspublications/new-bail-doctrine-recipe-banking-crises-and-depression-eurozone/

Havemann, R. (2018). Can creditor bail-in trigger contagion? The experience of an emerging market experience of an emerging market. Review of Finance, (July).

Hörisch, F. (2013). Finanzpolitik in schweren Zeiten - Eine Fuzzy-Set QCA der konjunkturpolitischen Reaktionen auf die Finanzkrise. Zeitschrift Fur Vergleichende Politikwissenschaft, 7(2), 117-141. https://doi.org/10.1007/s12286-013-0152-y

Hüser, A.-C., Hałaj, G., Kok, C., Perales, C., \& van der Kraaij, A. (2017). The systemic implications of bail-in: a multi-layered network approach.

Iyer, R., \& Peydró, J. (2010). Interbank contagion at work: evidence from a natural experiment. https://www.ecb.europa.eu/pub/pdf/scpwps/ecbwp1147.pdf

Magnus, M., Deslandes, G., \& Dias, C. (2018). Non-performing loans in the Banking Union.

Pericoli, M., \& Sbracia, M. (2003). A primer on financial contagion. Journal of Economic Surveys.

Ragin, C. C. (1987). The Comparative Method. Moving Beyond Qualitative and Quantitative Strategies.

Ragin, C. C. (2000). Fuzzy-Set Social Science.

Ragin, C. C. (2008). Redesigning Social Inquiry: Fuzzy Sets and Beyond. http://eprints.ncrm.ac.uk/1849/1/Resdisgning_social_inquiry.pdf

Ragin, C. C. (2014). The comparative method: Moving beyond qualitative and quantitative strategies. Univ of California Press.

Schneider, M. R., Schulze-Bentrop, C., \& Paunescu, M. (2010). Mapping the institutional capital of high-tech firms: A fuzzy-set analysis of capitalist variety and export performance. Journal of International Business Studies, 41(2), 246-266. https://doi.org/10.1057/jibs.2009.36

Single Resolution Board. (2016). Introduction to resolution planning. https://doi.org/10.2877/467651

Single Resolution Board. (2017). Decision of the SRB on Banca Popolare di Vicenza

Single Resolution Board. Decision of the SRB on Veneto Banca (2017). Retrieved from https://srb.europa.eu/sites/srbsite/files/srb-ees2017-11_non-confidential.pdf

Single Resolution Board. (2018). SRB Decision on ABLV Bank, AS (Vol. 8). 


\section{ENTREPRENEURSHIP AND SUSTAINABILITY ISSUES}

ISSN 2345-0282 (online) http://jssidoi.org/jesi/

2020 Volume 7 Number 4 (June)

http://doi.org/10.9770/jesi.2020.7.4(3)

Woodside, A. G., \& Zhang, M. (2013). Cultural diversity and marketing transactions: Are market integration, large community size, and world religions necessary for fairness in ephemeral exchanges? Psychology \& Marketing. https://doi.org/10.1002/mar.20603

Young, K. L., \& Park, S. H. (2013). Regulatory opportunism: Cross-national patterns in national banking regulatory responses following the global financial crisis. Public Administration, 91(3), 561-581. https://doi.org/10.1111/j.1467-9299.2012.02102.X

Zadeh, L. A. (1965). Fuzzy sets. Information and Control, 8(3), 338-353. https://doi.org/10.1016/S0019-9958(65)90241-X

\section{Acknowledgment}

Norat Roig-Tierno wish to thank Project GV/2019/063, funded by the Generalitat Valenciana, Spain, for supporting this research

Marc SANCHEZ-ROGER holds the university degrees of Telecommunications Engineering (UPC, Spain), Business Administration (UOC, Spain) and Engineering Master of Science (Télécom Bretagne, France). He works as vice president at Credit Suisse (London) in the Global Markets sector strategist team. Previously he worked for five years as senior banks analyst at BBVA (London) in the Credit Research team. He participates in meetings, conferences and events where he shares his views and opinions regarding the credit market and the banking and insurance sector with institutional investors, central banks and other market participants. Research interests: banking and finance, sustainable finance, financial markets.

ORCHID ID: https://orcid.org/0000-0002-9912-9351

María Dolores OLIVER-ALFONSO is a professor of Finance at the University of Seville, Spain. She has held management positions as Director and Vice Chancellor of Academic Planning and Research at the International University of Andalusia for 8 years. She has directed the research group "New Developments in Finance" ("Nuevos Desarrollos en finanazas") and is a member of the group "Finance and CSR" ("Finanzas and RSC") of the University of Seville. She works in Financial Risks and Microfinance, directing 5 doctoral theses. Furthermore, she participates in doctoral and master programs in local and foreign universities, works in research projects at national and regional level, and is responsible for research contracts with companies and institutions.

ORCHID ID: https://orcid.org/0000-0003-1347-8284

Carlos SANCHÍS-PEDREGOSA is a professor at the Faculty of Economic and Business Sciences of the Universidad del Pacífico (Lima, Peru). He obtained his International Doctorate in Business Economics at the University of Seville. In addition, he has conducted research stays at prestigious centers such as London Business School (R.U.), University College Dublin (Ireland) and the University of Pádova (Italy). Additionally, he is a member of the Research Group in Banking and Financing of Entrepreneurship (SEJ 555) where he develops his research line in Participatory Finance and Entrepreneurship. He has made numerous publications in high-impact international journals, among the most relevant are the Global Business Review, Operations Management Research and Performance Management Academy. ORCHID ID: https://orcid.org/0000-0002-0943-7335

Norat ROIG-TIERNO is a professor at the ESIC Business \& Marketing School. His research is focused on innovation, regional development and the application of qualitative methodologies. He has presented numerous papers at international conferences. He has published articles and books in international journals including Applied Geography, Journal of Human Development and Capabilities, Social and Policy Administration, Journal of Business Research, among others. He is or has been on the editorial board of several journals. ORCHID ID: https://orcid.org/0000-0002-7980-3548

Copyright (C) 2020 by author(s) and VsI Entrepreneurship and Sustainability Center This work is licensed under the Creative Commons Attribution International License (CC BY). http://creativecommons.org/licenses/by/4.0/ 